\title{
TESTING A HATCHBACK TYPE PASSENGER CAR FIRE
}

\author{
Anna SZAJEWSKA ${ }^{1}$
}

Review article

Abstract: $\quad$ The paper presents comments on statistics, referring to passenger cars fires in Poland. The
emphasis is placed on arsons. Experiments on fires started by the "Molotov cocktails"
are presented. The paper includes description of a fire test conducted on a hatchback car
with a LPG system. The photographs include the burning gas outflow, witnessed after
triggering the safety valves in LPG system. Hazards are pointed out, including those
concerning the driver, passengers, rescuers and others. The hazards are connected with
a leak of fuel or a gas stream and hazardous explosions of car parts. A description of
temperature taken on the car body surface is provided. An infrared camera has been used.
Car fire, combustion, arson of cars, temperature, infrared camera.

\section{Introduction}

A fire of a passenger car is of a unique nature. Familiarity with the process of its development and the associated phenomena is quite important not only for car users but also for firemen. It is also essential for experts preparing post-fire expert opinions for the investigation bodies. Understanding the process is also important for elaborating methods of minimizing the incidents consequences.

The number of passenger car fires is substantial because over six thousands of such fires are reported in Poland every year. This clearly implies economic and social importance. Intentional setting fire to cars is disquieting. For those reasons there is need of expanding knowledge related to the development of passenger car fires and finding ways of their preventing and suppressing.

The Main School of Fire Service carries out full scale researches on passenger car fires and several fire tests have been already carried out (Rybiński et al., 2011; Rybiński et al., 2012; Rybiński et al., 2013). The tests involved the participation of students working on their master theses. This type of testing is also carried out in other research centres (Okamoto et al., 2013; Simonova and Polednak, 2010; Svetlík, 2010, Svetlík et al., 2012).

\section{Fire statistics}

Data obtained from the annual report issued by the National Headquarters of the State Fire Serviceimply 7850 means of transport fires in Poland in 2013. The number includes 6337 fires of passenger cars and passenger car trailers. The total number of fires in 2013 was estimated at 126426. This shows that fires of passenger cars came up to $5 \%$ of all fires. According to the report of the Main Statistical Office prepared in 2013, the number of passenger cars registered in Poland was 19.4 million. The number of passenger car fires (including fires of passenger car trailers) per one million of such vehicles registered in Poland equalled 328. Fig. 1 contains a diagram showing the number of passenger car (and passenger car trailers) in five past years. In that period a certain insignificant fall in the number of fires was recorded. At the same the number of registered passenger cars increased by approximately 2.9 million, i.e. by approximately $18 \%$. It shows a clear decrease trend in relation of the number of passenger car fires and the total number of registered vehicles.

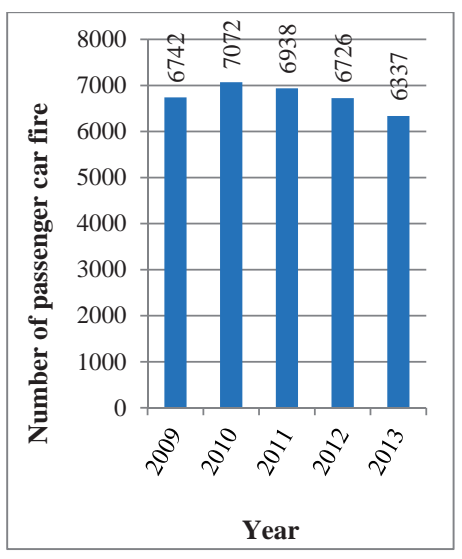

Fig. 1 Number of passenger car fires including fires of passenger car trailers in Poland in years 2009 - 2013

The Main School of Fire Service, Faculty of Fire Safety Engineering, Warsaw, Poland, ania.szajewska@gmail.com 
It may be presumed that this could be a result of the improving technical condition of vehicles, a decreasing number of modifications and repairs made in non-professional car service centers. The repairs and inspections of new marketed vehicles require specialist equipment and qualified staff, and so it is impossible to carry out any repairs or modifications on one's own. Car manufacturers place on the market cars that are characterised by higher safety and eliminate potential sources of fire hazard at the stage of designing and manufacturing. Despite that fact a car fire is still a frequent phenomenon and approximately 17 cars get burnt every day.

Approximately 600 fires a year are caused by intentional arson. The motive is generally vengeance or endeavours at extorting compensation. This year some parked cars were set on fire in streets of Warsaw and other cities, which was a shock to the community. There are also examples of setting fire under the impact of emotions or for terrorist reasons, which are primarily recorded during street demonstrations.

The phenomenon of intentional setting up cars on fire in streets of our cities has become intensified recently. There are also records of car arson examples during social unrest abroad. Basically "Molotov cocktails" are used to start a fire. As a rule these are bottles filled in 2/3 with easily flammable liquid with a tampon saturated with fuel, which serves as a cord-like igniting device. This mixture was effectively used in Finland during the defence war. They were also used by partisants of Armia Krajowa (Home Army) during the Warsaw Uprising. The mixture of petrol with oil better adheres to the car body than petrol by itself.

\section{Materials and methods}

\section{The measurement stand}

The current and previous tests were carried out on a test range with the use of hatchback cars. The Ford Escort 1.4 passenger car, with five doors and a lift back type, was a subject to complete burning. This vehicle had a petrol engine. It was additionally equipped with a LPG system containing a gas cylinder with multivalve including, safety valves (a pressure control valve and a fuse valve).

The LPG tank in the gas system is equipped with a multivalve that fulfils several functions, one of which is assuring safety during a car fire (Fig. 2). It becomes activated once the pressure achieves the value of $2.7 \mathrm{MPa}$. In such case gas permeates under the car via special venting ducts provided in the multivalve housing. The bursting pressure of the tank is $6.75 \mathrm{MPa}$. The multivalve contains a fuse valve, which becomes activated when temperature of the tank mantle reaches the value of $110^{\circ} \mathrm{C}$.
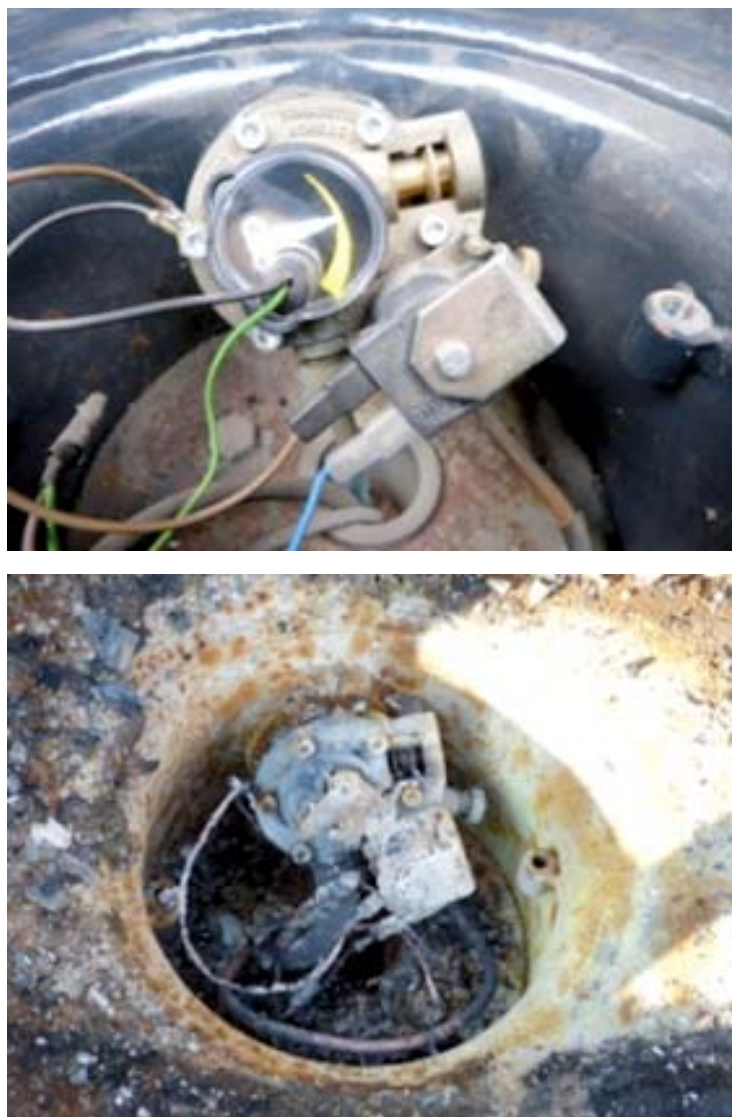

Fig. 2 Multivalve of the LPG tank before and after combustion

The car was fully furnished and in good working order. The LPG system was operational and had valid technical testing certificates. The electrical and ignition systems, as well as other subassemblies of the vehicle, were in good working order. A spare wheel was kept in the boot. The doors and windows were tight. The vehicle had a valid admittance to traffic and had been driven to the test range.

LPG and fuel tanks of the car were filled to about one-fourth of their volume. The thermoelectric temperature sensors were arranged inside the vehicle and on its body.

Five thermocouples were arranged inside the vehicle and two more on the car body surface (Fig. 3):

1 - in the passenger cabin under the ceiling,

2 - in the passenger cabin on the floor,

3 - in the engine compartment over the engine,

4 - inside the boot,

5 - inside the boot compartment close to the multivalve of the LPG tank,

6 and 7 - on the car body surface. 


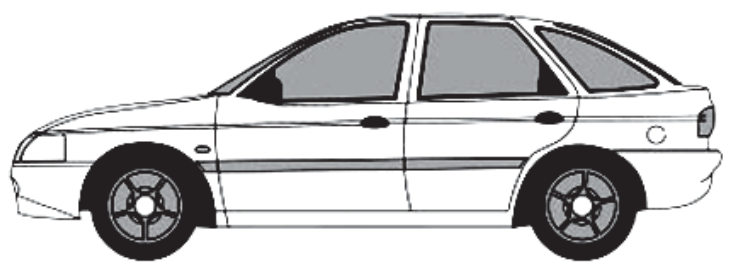

Fig. 3 Arrangement of thermocouples

The vehicle used for the testing was a hatchback type. In this type of chassis, from the technical point of view, the boot is only symbolically separated from the passenger cabin. Consequently, both the passenger cabin and the boot comprised a single compartment from the first minutes of fire.

An infrared camera was additionally used to measure the temperature on the car body surface. To allow a comparison of the results, measurement points 6 and 7 were designated on the body, where thermocouples were attached. This allowed the possibility of verifying thermometric measurements and the setting out the emissivity of body surface in combustion conditions.

The course of the experiment was recorded continuously with the use of digital cameras and an infrared camera. The readings of thermocouples were registered continuously as well.

\section{Results}

\section{Initiation of fire}

The fire was initiated by pouring one litre of petrol onto the car roof and igniting it with a torch (Fig. 4). This was meant to simulate arson using a "Molotov cocktail".

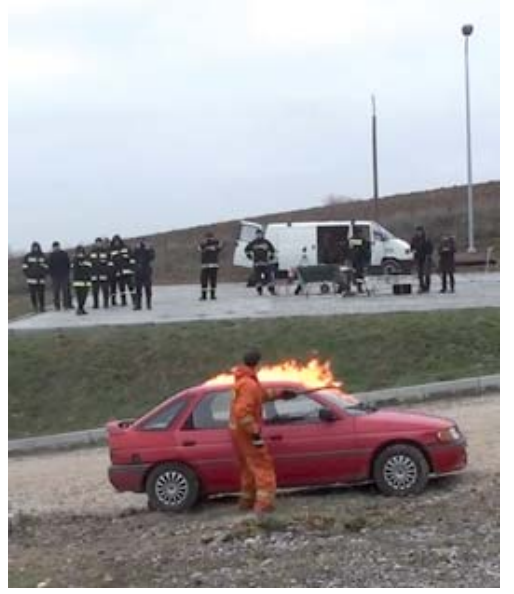

Fig. 4 Setting the Ford Escort car on fire. The measurement stand in the background
It turned out that pure petrol is not particularly suitable for this purpose. It runs down the car body quickly, and the fire from the burning petrol is not transferred onto car elements and vanishes after approximately 2 minutes, or it spreads very slowly onto seals situated in the lower part of the body. This primarily takes place on areas where dirt has become accumulated and stopped the rundown of petrol. Experiments of starting fire in the way described above were repeated a few times in tests with other vehicles and their results were similar.

The mixture of petrol with oil has a better viscosity and adheres much better to the car body surface, which makes it easier to initiate the fire with it. A mixture of petrol and oil was used in the experiment which involved the Ford Escort. This mixture ran down the car chassis slightly slower and accumulated in nooks close to seals. After approximately two minutes after initiation of the fire, the flame covered the rear left light of the car. The light fitting made of plastic started to melt and burn. The fire spread to the inside of the car through the burnt out opening and black smoke filled the passenger cabin. The internal surface of windows was covered by a layer of soot.

\section{Course of the car combustion}

The experiment was conducted on a test range in the following weather conditions:

air temperature $4^{\circ} \mathrm{C}$,

atmospheric pressure $1004 \mathrm{hPa}$,

wind speed $5 \mathrm{~m} / \mathrm{s}$,

fully overcast,

humidity $65 \%$.

The following listing includes a chronological order of all events occurring during the combustion of the car.

a) 00:00 Initiation of the fire.

b) 02:00 Start of the temperature growth in the boot and in the passenger cabin.

c) 03:50 Explosion of the powder fire extinguisher. The pressure increase in the extinguisher cylinder, caused by a temperature increase to about $150^{\circ} \mathrm{C}$, caused ripping out the valve of the extinguisher.

d) 04:00 Fall of the temperature level in the passenger cabin and boot was recorded, which took place as a result of released extinguishing powder.

e) 05:00 Unsealing and falling out of the window glazing on the left side at the back of the car body (after approx. 3 minutes). Air inflow did 
not intensify the burning process, because the fire was already suppressed by discharged extinguishing powder.

f) 10:00 Explosion of the left rear shock absorber.

g) $14: 25$ Falling out of the glazing on the boot cover. Air inflow caused an increase in the burning rate.

h) $16: 20$ Explosion of the left actuator in the boot lid.

i) 16:25 Automatic switching on of the horn, switching on of the lights and movement of the car. The car travelled on a section of approximately $0.6 \mathrm{~m}$ long. After approximately 1 minute the horn and the lights switched off.

j) 17:20 Unsealing of the windshield and temperature increase in the passenger cabin.

k) $17: 25$ Unsealing the tire in the front left wheel.

1) $18: 20$ Explosion of rear left shock absorber.

m) 21:15 Falling out of the windshield and transition to the phase of a fully developed fire. Temperature under the ceiling exceeded $1000^{\circ} \mathrm{C}$.

n) 22:00 Explosion of tire in the left rear wheel.

o) 22:30 Leak of fuel from the tank (Fig. 5). Burning fuel induced a rapid temperature growth in the passenger cabin and quick spread of the fire to the engine compartment.

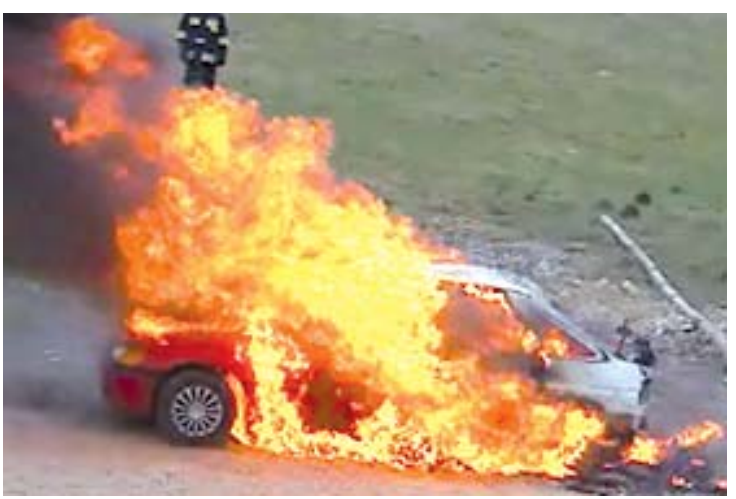

Fig. 5 Photograph of a vehicle after fuel leak from the tank

p) 23:00 Explosion of right rear shock absorber.

q) $24: 15$ Rapid spreading of the fire to the engine compartment.

r) 24:40 Triggering safety valves and emission of a burning gas flux (Fig. 6). This induced a temperature increase in the passenger cabin to the maximum value. The gas was released for approximately 1.5 minutes. Activation of the valve took place during a rapid temperature increase from approximately $150^{\circ} \mathrm{C}$ to approximately $650^{\circ} \mathrm{C}$, which was measured by a thermocouple attached close to the LPG tank (Fig. 7).

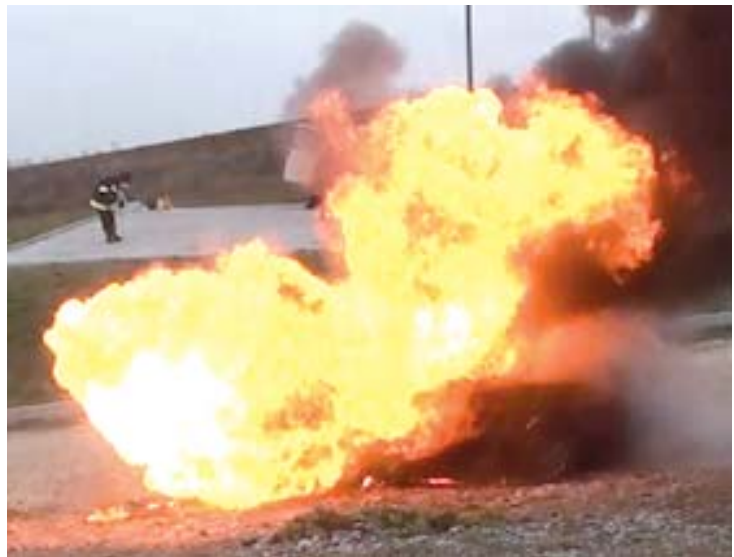

Fig. 6 Ignition of gas released from the LPG tank

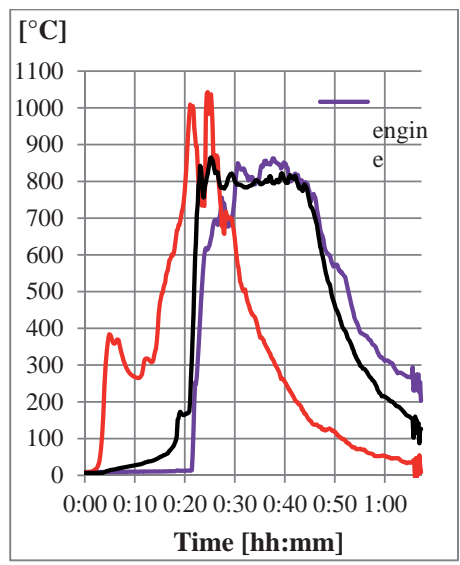

Fig. 7 Diagrams of temperatures during combustion of a Ford Escort for selected places: in the passenger cabin under the roof and on the floor, and in the engine compartment over the engine

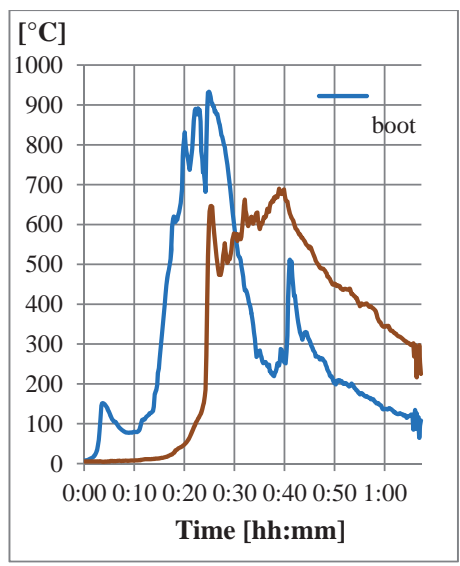

Fig. 8 Diagrams of temperatures during combustion of a Ford Escort measured with the use of a thermocouple situated inside the boot and thermocouple situated at the multivalve of the LPG tank 
s) 28:00 Unsealing the tire in the front right wheel.

t) 32:15 Explosion of the right front shock absorber.

u) 36:00 Unsealing the tire in the front left wheel.

v) 48:00 Commencement of the phase in which the fire dies out.

During the test the temperature in the passenger cabin reached the value of $1043^{\circ} \mathrm{C}$, and $863^{\circ} \mathrm{C}$ in the engine compartment.

\section{Use of an infrared camera}

The infrared camera was used to monitor the combustion process as supplementing of a digital camera, because certain details are better visible in infrared than in the visible light. This is especially applicable to observations made in smoke logging and in the darkness. In Fig. 9 smoke impedes observations of the front car door. They are, however, well visible in infrared.
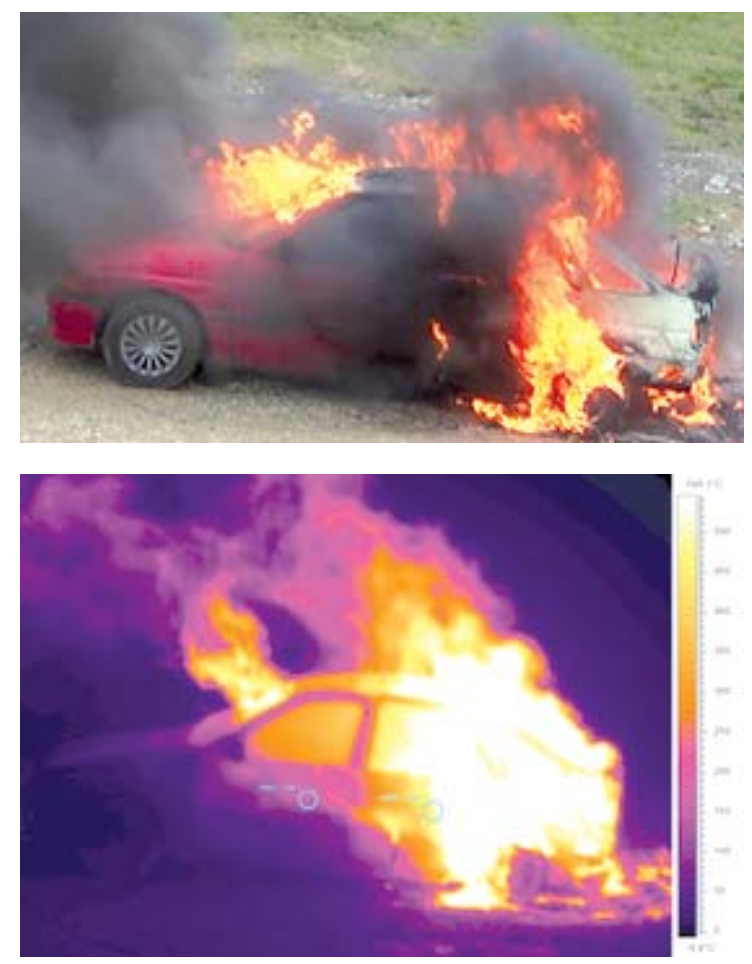

Fig. 9 Photograph of a car and a thermogram of the car body surface. At the measurement points marked on the thermogram, the average temperatures were: $158.1^{\circ} \mathrm{C}$ and $495.7^{\circ} \mathrm{C}$

Temperature measurements with the use of a camera were made difficult due to the fact that the coefficient of object emissivity was unknown. It is not easy to find data in literature concerning the emissivity values for the surface of metal sheets, seals, plastic elements or car windows, especially those at high temperature (Więcek and De Mey, 2011).

A camera Flir SC640 was used in this experiment. This type of camera is equipped with the Therma CAM Researcher computer programme, which allows for executing an advanced analysis of the obtained results. To determine the approximate value of the car body surface emissivity, coefficient temperature measurements were taken at the same point by the camera and the thermocouple. Measurement points are marked on the thermogram presented in Fig. 9. Using the Therma CAM Researcher programme, the car body surface emissivity coefficient was delimited. At a temperature of $500^{\circ} \mathrm{C}$ it equalled to 0.78 .

\section{Conclusion}

The executed testing showed that a fire of a passenger car was a hazardous phenomenon for participants of the incident, as well as for rescuers and for bystanders. Risk was posed by explosions of various subassemblies, which were caused by the growing pressure. Fragments of the car or the heat flux may cause injury to persons present in the vicinity.

It turned out that igniting a car is not as easy as it may seem to be. Pouring burning fuel over a car (tightly closed) does not always induce a fire. After such incident the driver has approximately two minutes to depart from the scene of the incident and undertake extinguishing actions.

The car fire temperature in the passenger cabin reached over $1000^{\circ} \mathrm{C}$. At such a high temperature all flammable materials became burnt completely. Consequently, a fire may also be intended to obliterate all traces of an offense. Temperature in the engine compartment is by approximately $200^{\circ} \mathrm{C}$ lower, but it is sufficient to melt down a lot of elements made of alloys containing aluminium. A passenger car burns with a great intensity for approximately half an hour.

The infrared camera is suitable to monitor the course of fires because it allows to record temperature changes at a safe distance. Nevertheless the measured temperature values may be encumbered by a considerable measurement error due to the coefficient of object surface emissivity being unknown. 


\section{References}

OKAMOTO, K., OTAKE, T., MIYAMOTO, H., HONMA, M., WATANABE, N. (2013). Burning behaviour of minivan passenger cars. Fire Safety Journal. 2013, Vol. 62, pp. 272-280. ISSN0379-7112.

RYBIŃSKI, J., JAKUBOWSKI, I., SZAJEWSKA, A. (2011). The research on the development of a passenger car fire. In: Požární ochrana 2010. Ostrava, pp. 312-314. ISBN 987-80-7385-102-6.

RYBIŃSKI, J, OMAZDA, A, SZAJEWSKA, A. (2013). Badanie rozwoju pożaru samochodu osobowego $\mathrm{z}$ wykorzystaniem termowizji (Testing the development of a passenger car fire with the use of thermovision). Pomiary Automatyka Kontrola. 2013, Vol. 59, No. 9, pp. 891-893. ISSN 0032-4140 (in Polish).

RYBIŃSKI, J., SKALNY, M., SZAJEWSKA, A. (2012). Test fire of a passenger car. Technika Transportu Szynowego. 2012, No. 9, pp. 1453-1459. ISSN 1232-3829.

SIMONOVA, M., POLEDNAK, P. (2010). Poznatky z experimentálnho overovania požiarov osobnŷch automobilovŷch vozidiel v skušobnej štǒlni (Findings from experimental verification of passenger motor car fires in closed space). In: Požární ochrana 2010. Ostrava, 2010, pp. 324-326. ISBN 987-80-7385-087-6 (in Slovak).

SVETLÍK, J. (2010). Požiar v motorovompriestore osobného motorového vozidla. In: Zborník zo 4. medzinárodnej konferencie Ochrana pred požiarmi a záchranné služby 2010. Žilina, 2010, pp. 324-326. ISBN978-80-5540208-6 (in Slovak).

SVETLÍK, J., POLEDNAK, P., MAKOVICKA OSVALDOVA, L. (2012). Poziaro osobnich motorovych vozidiel. Spectrum. 2012, Vol. 12, No. 1, pp. 74-78. ISSN 1211-6920, (in Slovak).

WIĘCEK, B., DE MEY, G.(2011). Termowizja w podczerwieni podstawy (Elements of thermovision in infrared). In: Wydawnictwo PAK. Warsaw, 2011. ISBN978-83-926319-7-2 (in Polish). 